\title{
Landscape Planning at the Catchment Scale (The Case Study of Rhodope Mountain Representative Catchments)
}

\author{
Havza Bazında Peyzaj Planlaması \\ (Rodop Dă̆ı'nın Tipik Havzalarından Örnek Bir Çalışma)
}

\author{
Bilyana BORISOVA \\ Sofia University "St. Kliment Ohridski”, Faculty of Geology and Geography, Department of Landscape Ecology and \\ Environmental Protection, Sofia, Bulgaria
}

\begin{abstract}
This article portrays the results form the first stage of an attempt at landscape planning in the upper watershed of the Arda River in the Western Rhodope Mountain, South Bulgaria. The study applies the concept of multifunctionality of landscape systems focusing on resource evaluation and territorial planning using the natural watershed boundaries. The upper valley of the Arda River is a major national-level resource regarding water and forest resources, including their renewable energy potential. At the same time, high ecological risk (primarily floods and landslides), enhanced by the global climate change, characterizes the Arda watershed. This study uses watershed models to interpret and analyze landscape maps and primary data on ecosystem services. It also analyzes public attitudes regarding the utilization of local natural capital, which are determined by the peripheral situation of the area and the high dependency of the locals on the landscape resources. The investigation proposes lead landscape indicators and functional zoning of the area, which allow for locally adequate and sustainable territorial management.

Key words: landscape planning, multifunctionality, catchments, ecosystem/landscape services, functional zoning, landscape stabilization.

Özet: Bu makale, Bulgaristan'nın güneyinde, Rodop Dağı'nın batısındaki Arda nehrinin yukarı havzasında yapılan peyzaj planlamasının ilk evresine ait sonuçları ortaya koymaktır. Çalışma, doğal havza sınırlarını kullanarak bölge planlaması ve çok fonksiyonlu peyzaj sistemleri kavramını uygulayarak kaynak geliştirmeye odaklanmıştır. Arda nehrinin yukarı çı̆̆ırı, yenilenebilir enerji potansiyelini de içeren, ülkedeki başlıca su ve orman kaynaklarına sahiptir. Aynı zamanda Arda havzası küresel iklim değişikliğinin etkilediği yüksek ekolojik risk (başlıcaları taşkın ve heyelanlar) altındadır. Bu çalışmada peyzaj haritaları ve ekosistem hizmetlerinin temel verilerinin yorumlanması ve analizinde havza modelleri kullanılmıştır. Aynı zamanda burada yaşayan yerel halkın doğal sermayeyi kullanım davranışları da analiz edilmiştir çünkü alanın etrafindaki yakın çevrenin etkisiyle yerel halkın doğal kaynaklara bağımlılı̆̆ı büyüktür. Araştırma başlıca peyzaj göstergelerini ortaya çıkararak alanın fonksiyonel kuşaklara ayrılmasını önermektedir, bu durum yerel eşitliği ve sürdürülebilir bölgesel yönetimi sağlayacaktır.

Anahtar sözcükler: arazi planlaması, çok fonksiyonluluk, havzalar, ekosistem/peyzaj hizmetleri, fonksiyonel bölgeleme, peyzaj stabilizasyonu.
\end{abstract}

\section{Introduction}

This article portrays the results from the first stage of an attempt at landscape planning in the upper watershed of the Arda River in the Western Rhodope. The main objective is the optimization of current land use. The study uses watershed models to interpret and analyze landscape maps and primary data on ecosystem services. The investigation proposes lead landscape indicators and functional zoning of the area, which allow for locally adequate and sustainable territorial planning and management.

\footnotetext{
* Supported by Sofia University's "Alma mater" Humanities Complex
} 


\section{Theoretical background}

The study applies the concept of multifunctionality of landscape systems focusing on resource evaluation and territorial planning using the natural watershed boundaries.

Landscape ecological concepts and metrics can assist planning for sustainability as tools that are suitable to address the spatial dimension of land use planning and management issues. Landscape ecology as trans-disciplinary science, provides an appropriate scientific approach to inform planning at a higher level of integration, and to plan comprehensively for all planning sectors (Botequilha Leitão and Ahern, 2002).

Selecting the appropriate "scale" in landscape planning is a major issue due to the specific nature of the land area subjected to planning. It determines a number of other features of the process the choice of approach to planning tools, the temporal aspect of achieving the intended results, the social and economic impacts, the methods of monitoring, etc. The selection of "scale" as "work space" is related to clarification of two conditions that are important throughout the whole process of planning and management of the area - scale and boundaries.

Scale is a key issue in sustainable planning (Botequilha Leitão and Ahern, 2002). The term is related to the methodology of the planning process and to the purely technical procedures of its implementation. The overall review of the issue shows that the important concepts in the context of sustainable landscapes are: scale survey of the area, planning scale and management scale. These concepts are often interpreted in different ways, but their meanings should be reconciled among each other. Landscape ecologists and planners stressed the importance of "landscape scale" or "work at the scale of the landscape" (Forman, 1995; O'Neill et al., 1989; Haase, 1989; Zonneveld, 1989; Lavers and Haines-Young, 1993; Gustafson, 1998; Ahern, 1999; Blaschke and Petch, 1999; Fry, 2001; Botequilha Leitão and Ahern, 2002; Hawkins and Selman 2002; Potschin and Haines-Young, 2006; Blaschke, 2006; Von Haaren et al. 2008). These are conceptual and methodological issues. The concept of "scale" here stands for integrity, relative independence of the natural system in a hierarchical structure, with a clear geographical scope and the possibility to define boundaries in space.

This study has adopted the following interpretation of the term "landscape": a spatially heterogeneous system, which shows a characteristic ordering of elements. Landscapes themselves have resulted from the long-term interactions of natural abiotic, biotic and anthropogenic processes and are complex systems in which many components are interdependent (Mücher et al., 2010).

We endorse to the position that a balance between basic human needs and ecological integrity should be assured over time. An integrated approach to physical planning and management should be pursued with a focus on the ecosystems (the source), rather than solely on the natural feature or landscape quality to be explored (the resource). This approach should always be applied with due consideration for the production capacity of the system (Botequilha Leitão and Ahern, 2002). The concept of "multifunctionality" provides a more anthropocentric focus of landscape-ecological research; a "sustainable landscape" is a system that ensures sustainable production of goods and services relevant to society (Potschin and Haines-Young, 2006).

In addition, we used an alternative for spatial interpretation of the available information (traditional information network in grid cells of one square $\mathrm{km}$ ) that is more accurate, spatially relevant, and objective for the purposes of the analysis of natural phenomena, processes, and systems natural boundaries. Our decision was logically limited to the use of catchments as natural systems that are important functional entities and have naturally defined boundaries. Catchments are an essential link on the landscape scale, the smallest natural unit of the landscape that combines linked terrestrial and aquatic ecosystems (Hornung and Reynolds, 1995).

Coordination of landscape planning with land use management in administrative boundaries is a huge challenge. The "catchment" has potential to facilitate this connection. In this case it has an additional function - for skillfully managing the landscape processes in conditions which are suitable in terms of administrative practice (Bulgarian River Basin Directorates, Bulgarian Ministry of Environment and Water, Ministry of Agriculture and Foods, Regions, Municipalities), including monitoring of the landscape plans. 


\section{Materials and methods}

\subsection{Study Area}

The study area (Figure.1) coincides with the territory of Smolyan Municipality (Figure. 2), which is selected as a peripheral region with the high dependency of the locals on the landscape resources Inatural capital. It is located in the transition zone between Western and Eastern parts of The Rhodope Mountains. These lands are composed of fragments of the geologically older Balkan Peninsula. Their current topography is highly diverse in its relief ranging from extensive hilly territory to high mountains and is characterized by a mature river system. The complex geological texture, the particular hydro-climatic conditions, which have been formed under the strong influence of the Mediterranean climate and the peculiarities of the paleogeographic development of the Balkan Peninsula have played a decisive role in shaping the landscape of a region.

The relief is a diverse combination of uplands, dominated by the mounts of Mursalitza (2191 m.) and Prespa $(2000 \mathrm{~m}$.). The landscapes of Smolyan Municipality are almost equally divided between two types - cool humid and temperate humid. The natural forest landscapes (predominantly spruce forest) are very well preserved there (65\% of the area). Mountain pastures with mainly anthropogenic origin, are the second largest type contemporary landscape. There are no extensive arable lands, only small patches within the matrix of forest (Nedkov, 2009). The landscape is enriched by the complex and varied network of the Arda River and its tributaries, where wide river valleys alternate with short but deep gorges: complex, dynamic, and contrasting. The upper valley of the Arda River is a major national-level resource regarding water and forests, including their renewable energy potential. At the same time, the upper part of Arda Catchment supports stability of the landscapes in the middle watershed (Eastern Rhodope), which is characterized by high ecological risk (primarily floods and landslides), enhanced by the global climate change. Typical of the Eastern Rhodope are their sub-Mediterranean forest landscapes, developed on shallow stony soils, covered by grasses and prickly bushes characteristic for the area, in close proximity to complexes of cliffs and rockslides (Borissova, 2009). The area's landscapes are quite fragmented pastures alternating with cultivated land in hilly areas.

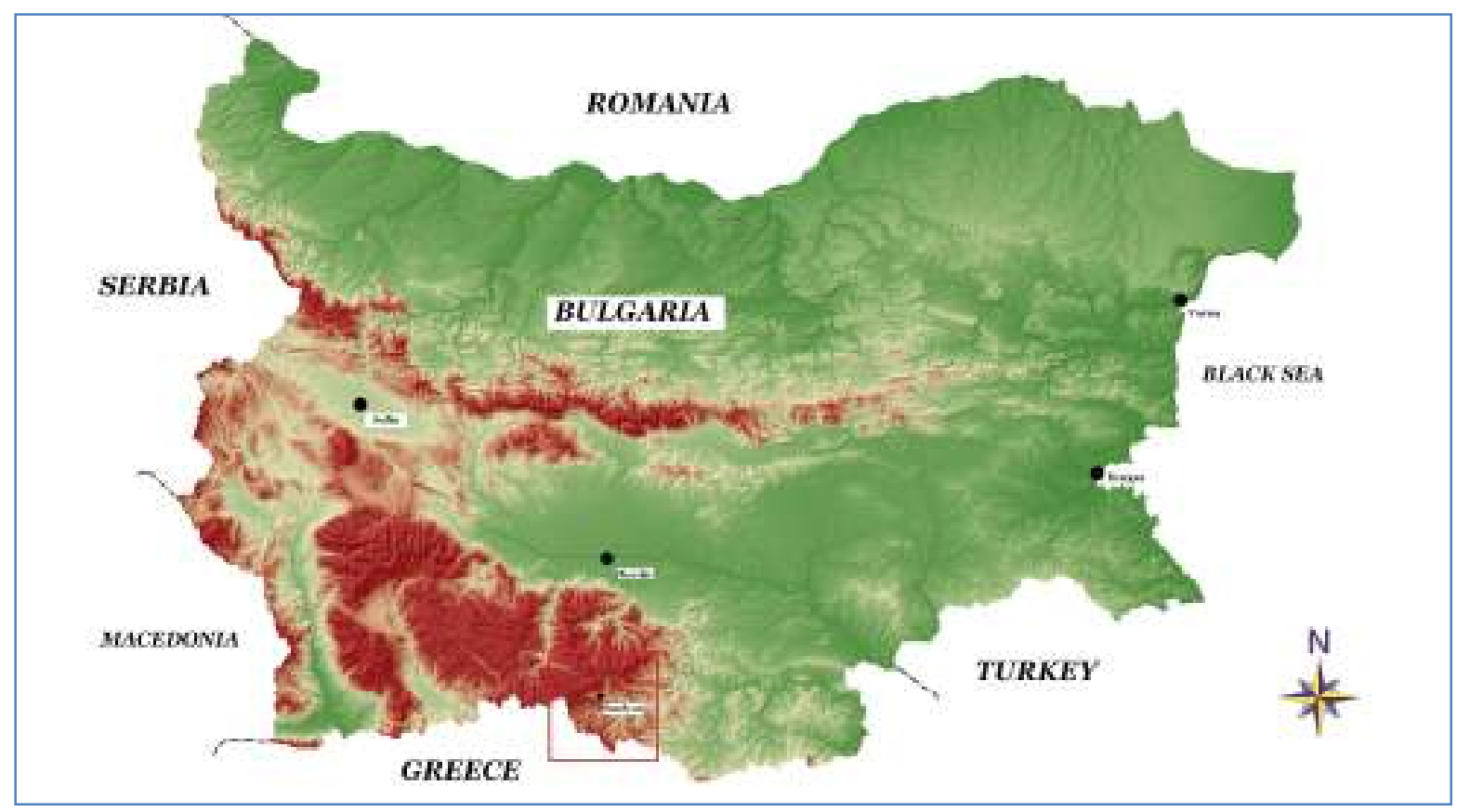

Figure 1. Study Area 


\section{Bilyana Borisova}

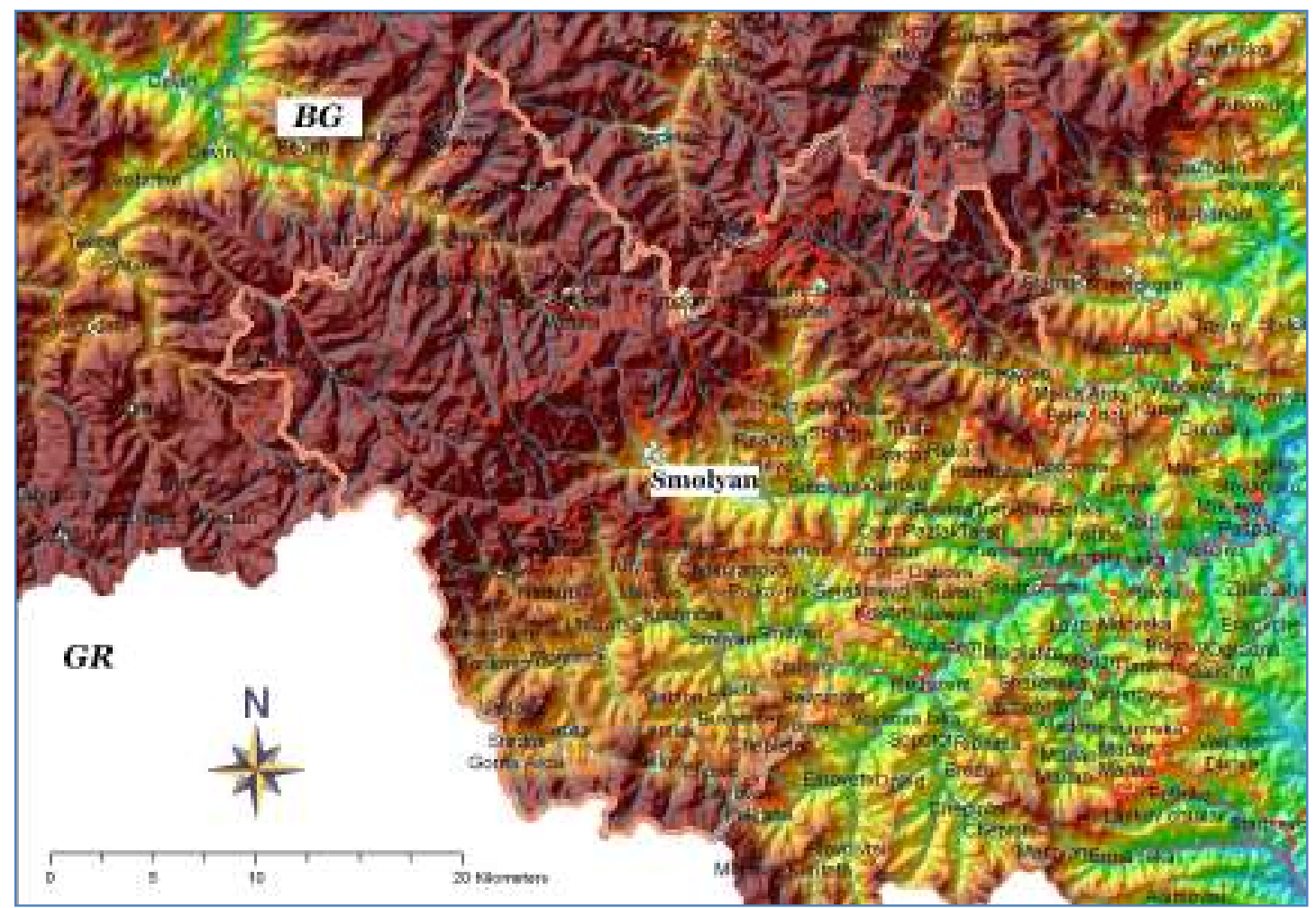

Figure 2. Smolyan Municipality

This analysis shows the structural variety of the landscapes to be the product of their geological development, with rock formations varying in age, created under changing tectonic conditions. The primary factor here is dynamic events during the Paleogene (30 million years ago), a period in which the massif underwent deep rifts and was subjected to substantial volcanic activity. The relict volcanogenic structures have retained a substantial part of their primary morphology and appearance to the present day, forming the peculiar landscape of the region. Another factor responsible for formation of the landscape is the hydro-climatic characteristics of the area and, in particular, the extreme variation in their natural regimes. These are related to the orographic precipitation and river flows.

The richness of the vegetation in the landscapes is explained by the Rhodope's location, straddling the biome of the coniferous forests (Aciculilignosa, dominated in the area by Picea abies or in some places by Pinus sylvestris, Abies alba, Abies borisi-regis), deciduous forests and bushes (Aestilignosa - Corylus avellana, Crataegus monogyna, Tilia tomentosa, Carpinus betulus, Ostrya carpinifolia, Acer pseudoplatanus, Fraxinus excelsior) and that of the perennial, sclerophyll forests and bushes (Durilignosa) in the east, which suggest mutual penetration. The variety of fauna in the landscapes is the largest in Bulgaria with standout species from the mammals (Ursus arctos, Canis lupus, Felis silvestris) and ornitofauna (Асенов, 2006).

\subsection{Data}

A geographical database, created for handling all analytical procedures in landscape delineation is used for both analytical and purely visualization purposes. The primary sources of spatial information which are integrated in the geographical database include a SRTM digital elevation 
model $^{*}$ and vector layers representing various characteristic of the territory. The layers are derived from a database produced within the "Study of Integrated Water Management in the Republic of Bulgaria" project". In addition, the study used landscape maps (Gikov and Nedkov, 2009) created with the project "Conservation of Globally Significant Biodiversity in the Landscape of Bulgarian Rhodope Mountains". The decision to use these landscape maps is based on two main items: the analysis of landscapes within the Smolyan Municipality as part of the overall landscape diversity of the Rhodope Mountain, and, second, the primary evaluations of ecosystem services in the municipality within the above project.

\subsection{Method}

The structuring of the research process and the analyses of the landscape systems are influenced by the landscape stabilisation approach (Miklós, 2010), development of a landscape program and the conducting of functional zoning of the landscape and the concept of "Eco-civic" optimization as a nested framework for planning and managing landscapes (Brunckhorst et al., 2006).

The landscape stabilisation approach applies to the comprehensive landscape planning at a range of scales, but can be used only as a method of landscape analysis. The approach aims to strengthen and enhance the functions of the landscape elements that highly contribute to system's sustainability. It places special emphasis on the "eco-stabilizing measures" (Miklós, 2010), focused on practical arrangements for the maintenance of landscape features, conserving and enhancing biodiversity and scenery, and landscape functions, such as water and soil protection, air purification, and soil erosion control. The understanding of 'stability' relates to the capacity of a landscape to remain unaltered or to regenerate quickly after anthropogenic or natural perturbance. The basis of this planning approach is to map at various scales those elements in the landscape that are inherently stable or unstable, and to determine from these maps a network of landscape elements to act as 'biocentres' and 'biocorridors' (Bucek et al., 1986). The existing network can then be analysed to identify where landscape creation or rehabilitation is necessary to fill strategic gaps (Figure 3). The basic concept involves retaining existing ecological infrastructure, and then creating "more of the same" landscape elements in deficient areas (Hawkins and Selman, 2002).

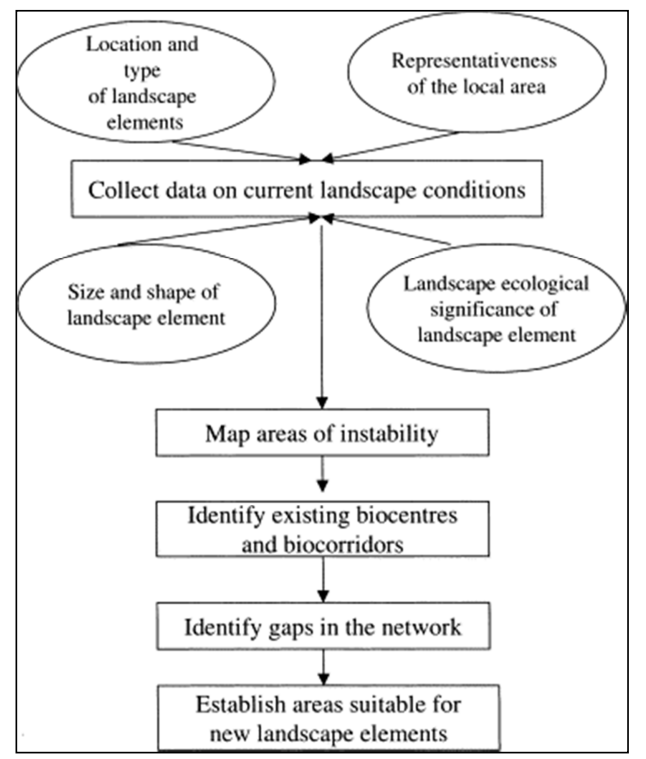

Figure 3. The landscape stabilisation model (Hawkins and Selman, 2002)

\footnotetext{
* Source: NASA, www2.jpl.nasa.gov/srtm/

${ }^{\dagger}$ Blagoevgrad Basin Directorate, Financed by the Japan International Cooperation Agency (JICA)

* Rhodope Project, a joint initiative of the United Nations Development Programme (UNDP) and the Ministry of Agriculture and Forestry of Bulgaria (MAF), funded by the Global Environment Facility (GEF)
} 


\section{Bilyana Borisova}

"Eco-civic" optimization is a method that leads to a redefinition of regional frameworks for natural resource management in conjunction with local authorities and other services (Brunckhorst et al., 2006). This method aims at forming a "region", which meets the requirements of the population and motivate them for the integrated management of natural resources. The "eco-civic region" unites the areas of interest of most residents and communities and, therefore is likely to be politically acceptable in terms of implementation reforms.

\section{Overview of the most important steps for landscape analysis and planning process}

The first step implemented was analysis of landscape structure in a horizontal perspective. The analysis focuses on a set of characteristics of landscape structure, including identification of the landscapes types dominant in size, spatial extent, configuration, consistency of landscape pattern on the line of watershed, level of connectivity, fragmentation, anthropogenic processes, and negative natural processes in contemporary landscapes.

The study was conducted on the basis of the lowest hierarchical levels of landscape (identified on the basis of the rock fundament - Figure 4), enabling identification of the dominant processes in the contemporary landscape (denudation, erosion, karstification) and the formulation of assessments about the stability of landscapes and their current dynamics. Figure 5 reflects the ratio of the areas of the dominant landscape-level types. It shows that area is dominated by erosive denudation landscapes on metamorphic rocks (b), followed by such on consolidated sediments (e) and volcanic rocks (c). The overall impression is of high landscape diversity and preservation of natural landscapes. However, there is greater dynamics of processes in contemporary landscapes (particularly on volcanic rocks and unconsolidated sediments) that requires that attention be placed on the anthropogenic pressure on the landscapes of the area and control of their expansion into the higher parts of the catchments.

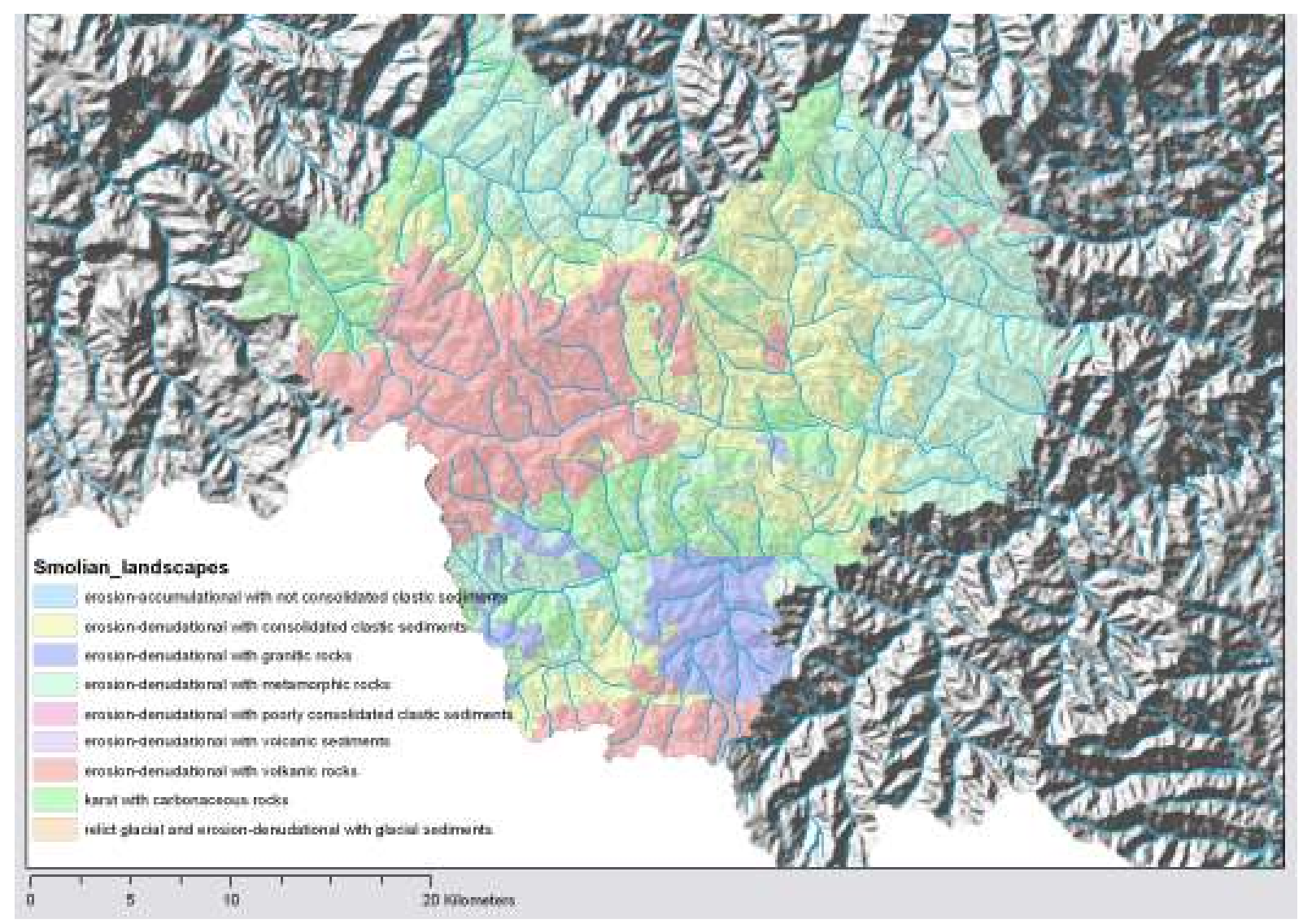

Figure 4. Landscape types in the Smolyan municipality at the lowest hierarchical level 


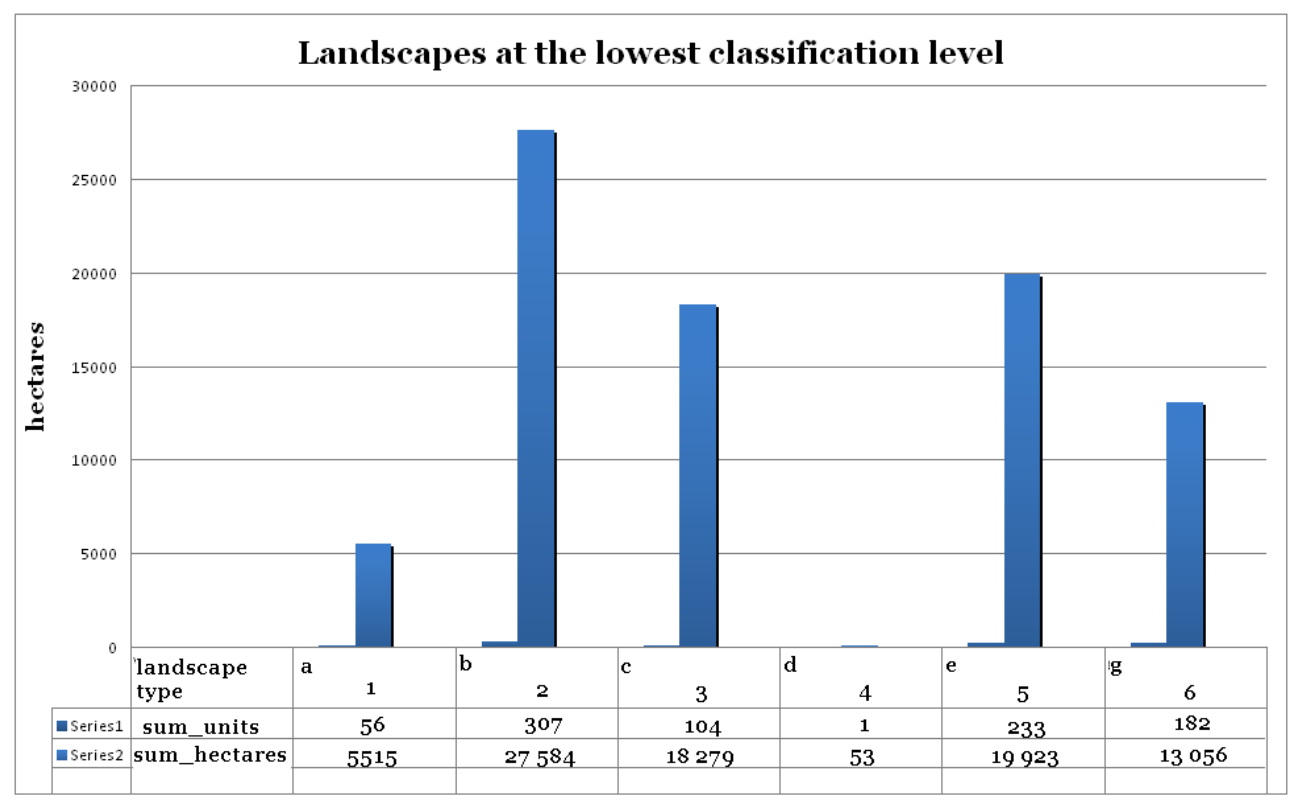

Figure 5. Ratio of the areas of dominant landscape types at the lowest hierarchical level

According to survey data (Nedkov, 2009) the indicator "average connectivity" for the land cover class within the region is 92.3 for natural forest. Other important data for natural forest is the number of large patches (57), percentage of the area in the transitional class (6.3) and percentage of the area that is in the edge class - with the value 26.2. Forest fragmentation in the Smolyan Municipality is highest for deciduous forest. The main reason is that they occupy the lower, more urbanized part of the municipality with higher anthropogenic impact.

The next step is related to the analysis of landscape structure in a vertical perspective (Figure 6). Figure 7 shows the proportions among the contemporary landscapes in the area and the main landscape functions: landscapes of natural forests and rock outcrops clearly dominated (50 000 ha in the 300 individual landscape units in the territory). Very close in value are the landscapes of mixed areas of agriculture and natural vegetation, classified as averagely modified landscapes that occupy nearly 9500 ha in 150 separate units in the territory, artificial forests follow with 9,000 ha in 170 landscape units, and finally the transitional forest and shrub vegetation (8400 ha) in 160 units. The latter has great significance for landscape diversity, but the particular location of these units within the landscape is also important, as well as its interrelations with the surrounding landscapes. These three types of contemporary landscapes create the effect of landscape diversity. This is due to the fact that despite the huge difference in their total area (27000 ha) to forest landscapes (50 $000 \mathrm{ha})$, they form numerous independent units (480) to 300 for forest. The location of mixed areas and transitional forest-shrub vegetation deserve special attention. The effect of fragmented landscapes increases in the east, associated with the rising anthropogenic changes in landscapes on relatively small areas. Widespread anthropogenic activity is tied to river valleys. Anthropogenic changes are observed everywhere even in the head sections of the smallest tributaries of Arda, Vacha and Chepelarska rivers.

A separate phase of the study includes additional analysis of the dominant landscape functions for each catchment (Figure 8). 


\section{Bilyana Borisova}

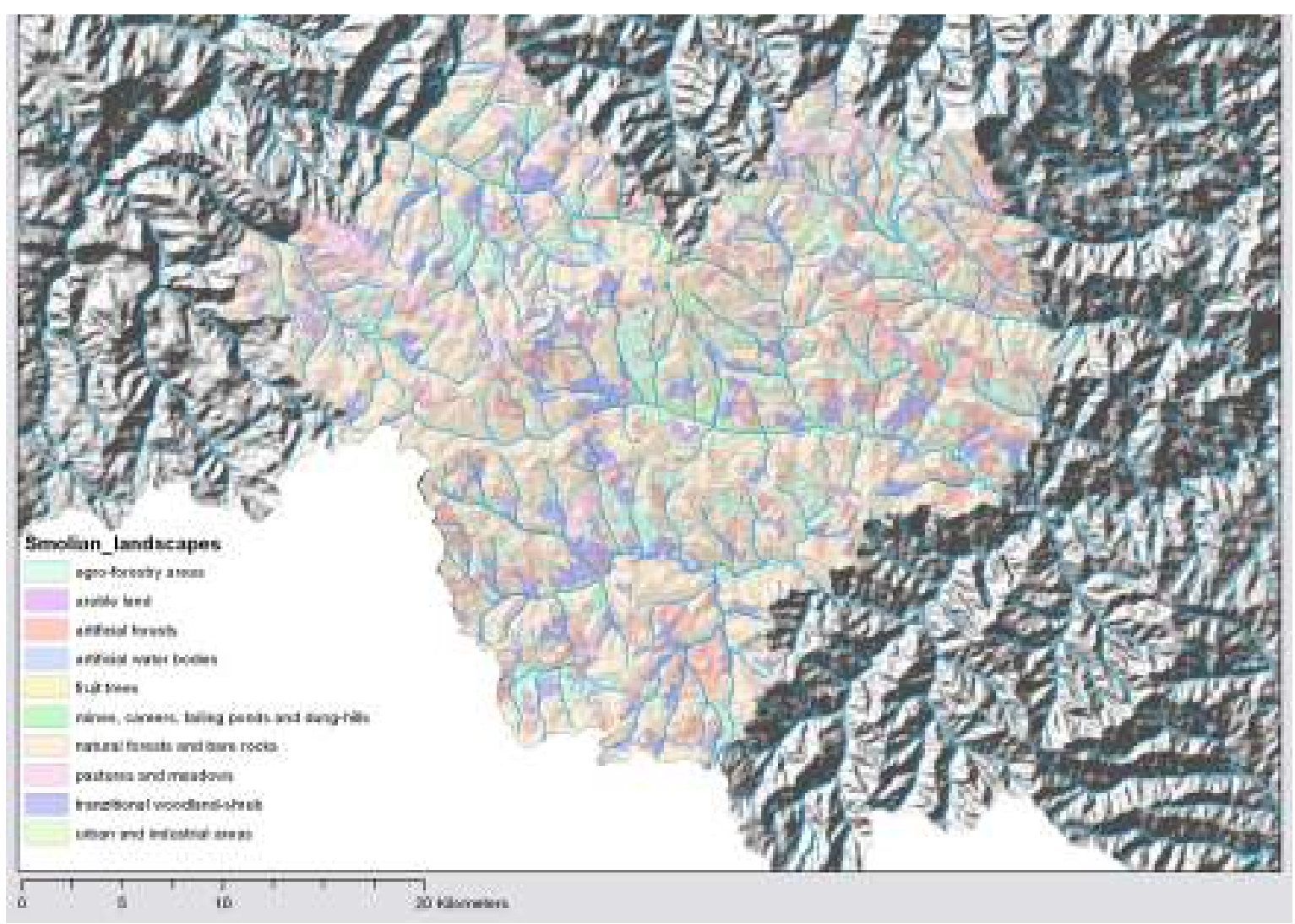

Figure 6. Landscape structure in a vertical perspective - the main landscape functions in land use.

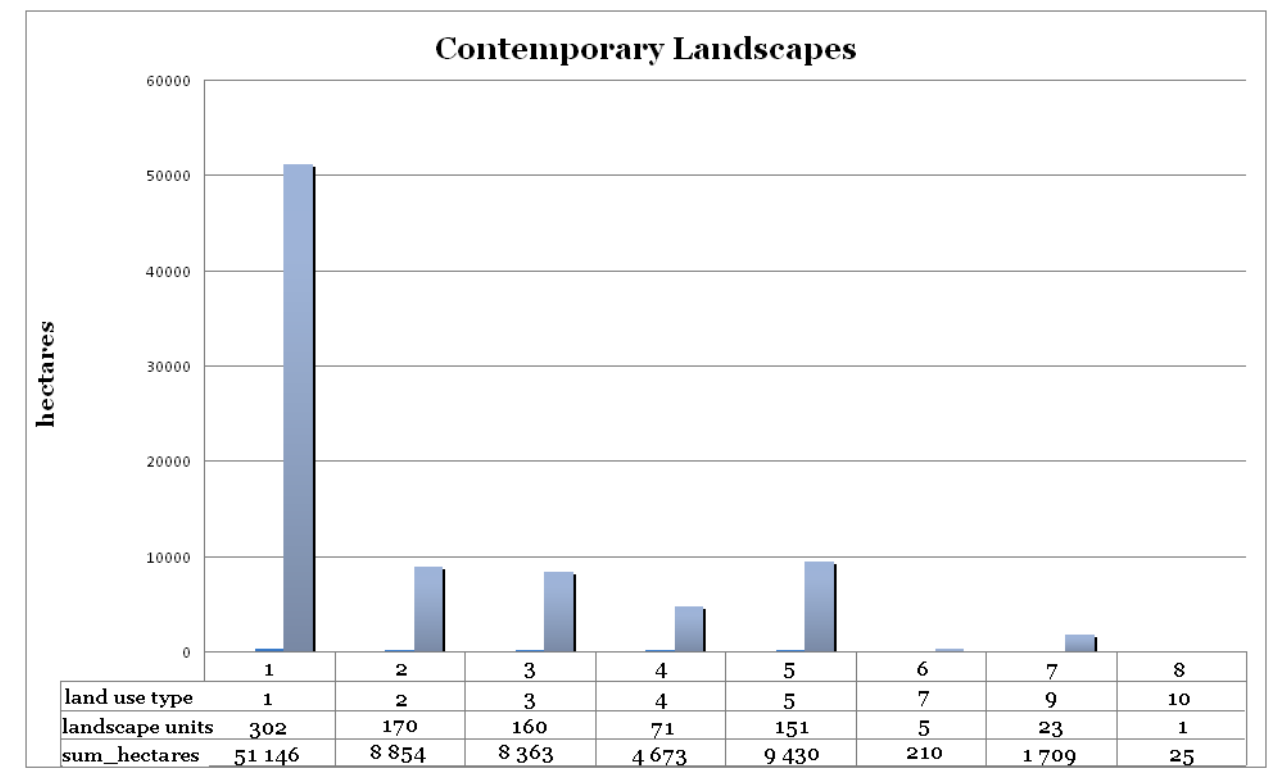

Figure 7. Proportions among the contemporary landscapes in the area and the main landscape functions 


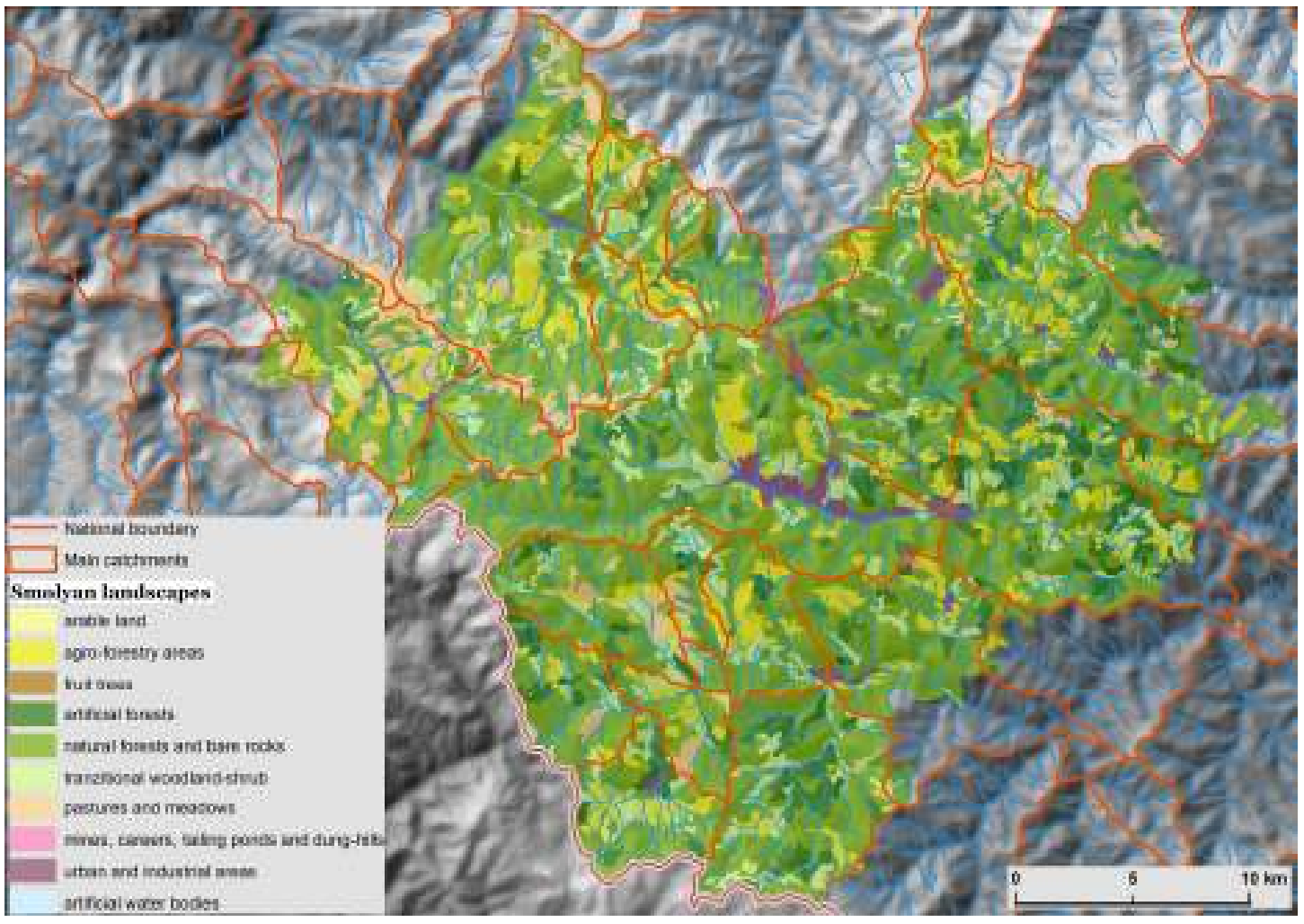

Figure 8. The configuration of the major watersheds within the area studied

\section{Results}

\subsection{Defining functional zones}

In the process of functional zoning, this work examined the strategies and plans for development of the territory to establish the local priorities. These include more intensive land use with emphasis on further economic development of the region, greater attention to the state of current landscapes and creating conditions conducive to preservation of landscape stability and landscape functions, including ecosystem/landscape services (Table 1).

Table 1. The valuation of ecosystem services provided by landscapes of Smolyan municipality using landscape typology data set (Nedkov, 2009)

\begin{tabular}{|l|c|c|c|}
\hline \multirow{2}{*}{ Land unit } & \multicolumn{3}{|c|}{ value thousands BGN/year } \\
\cline { 2 - 4 } & PRO & RE/CU/SU & Combined \\
\hline Forest & 13591 & 71208 & 84799 \\
\hline Grassland & 500 & 1056 & 1556 \\
\hline Inland waters & 72 & 1203 & 1275 \\
\hline Wetlands & 0 & 0 & 0 \\
\hline Agriculture & 3388 & 2231 & 0 \\
\hline Urban areas & 0 & 0 & 93249 \\
\hline Total & 17551 & 75698 & 0 \\
\hline PRO-provisioning services; $R E-$ regulation services; $C U-$ cultural services; SU-supporting services
\end{tabular}


Zone A - natural and semi-natural landscapes (including grassland and pastures or transitional areas) of high value to the sustainability of the territory (Figure 9). Maintaining the natural state of forests (especially those in the high catchments) will have a decisive role in supporting the natural dynamics of the watersheds and reducing their vulnerability to anthropogenic influences and within the context of climate change (eg, heavy rainfall; maintaining conditions, which are conducive to transformation of surface runoff to underground waters, etc.).

Recommendations: Anthropogenic activity is not recommended in the area.

Zone B - vulnerable anthropogenized landscapes. These areas need reduction of the intensity of anthropogenic pressure or change of the type of land use. Current anthropogenic pressure on these landscapes exceeds their self-regulation ability and threatens their sustainability.

Recommendations: Special attention should be paid to floodplain landscapes (and sectors of influxes), especially those that are under the influence of urban structures. It aims to strengthen the local erosion basis to control denudation processes and erosion risk; to sustain water resources and strengthen the landscape functions in the surrounding landscape regions of the watersheds of Arda, Vucha and Chepelarska rivers (exo-dynamic processes, microclimatic conditions; essential ecological processes; dynamics of water; soil destruction prevention).

Zone C - semi-natural and anthropogenized landscapes. Includes mixed areas or areas with often alternating natural and cultural vegetation - forestry and agriculture - especially in more traditional forms of land use: small size and scattered farmland, pastures and meadows.

Recommendations: Maintenance of contemporary forms of land use and controlled expansion of built infrastructure. Development of recreation and tourism is admissible, but it should be done with special attention to the transport network, since it is main factor for landscape fragmentation.

Particular attention should be paid to small-area units or units at high altitude. In these areas it is important to maintain a territorial link between habitats with natural vegetation. In those cases where it is necessary to expand farmland areas, this expansion should be offset by increasing the areas of natural landscapes in the vicinity. Diversity is necessary for sustaining landscape functioning but the degree of diversity should not differ much from that which is "natural" for the region.

Zone D - urban landscapes.

Recommendations: Conservation of natural fragments of landscapes in urban conditions, especially in riparian areas. Maintain the periphery of urban environment by creating green buffer zone for gradual entry in the landscape pattern of the area. 


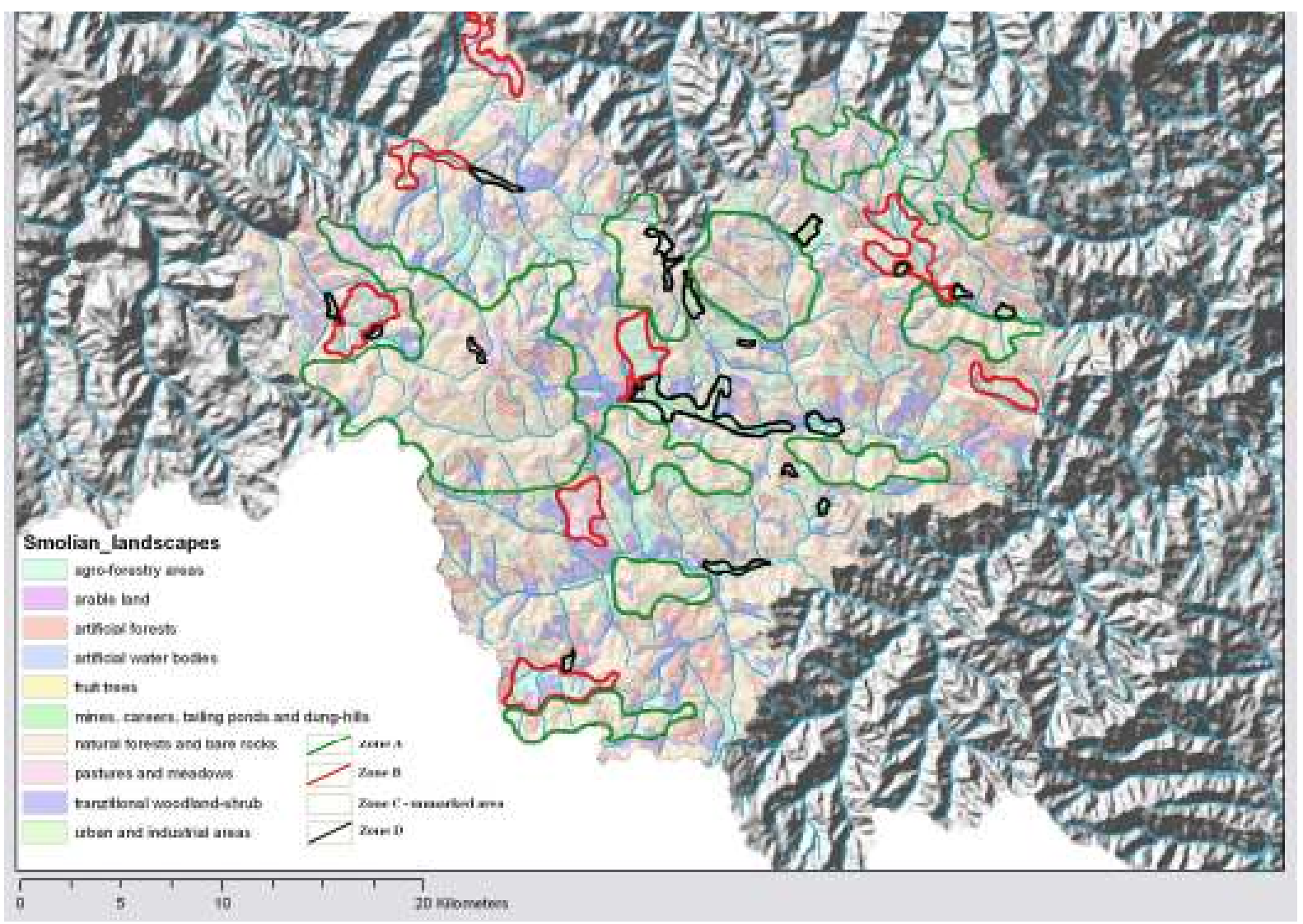

Figure 9. Functional zoning of landscapes

\subsection{Defining ecological framework}

A system of landscapes with ecological significance for the region's sustainability. The results are reflected in Figure 10. The dominant part of landscapes involved relate to natural or semi-natural landscapes in the upper catchments and important river flows. The red line separates vulnerable landscapes that require human attention and maintenance of ecological balance. In the process of identification of ecologically significant landscapes this author takes into account the following criteria: biodiversity, vulnerability of landscapes, natural processes of risk to human health and activities, landscape types representative of landscape diversity, heavily modified landscapes under the influence of contemporary environmental issues, cultural landscapes as sites of natural and cultural heritage. Artificial wooded forests do not have conservation value, but in this paper are accepted for units with supportive role on the landscape structure of the surrounding area and are included within the environmental framework on an equal basis with natural forests. 


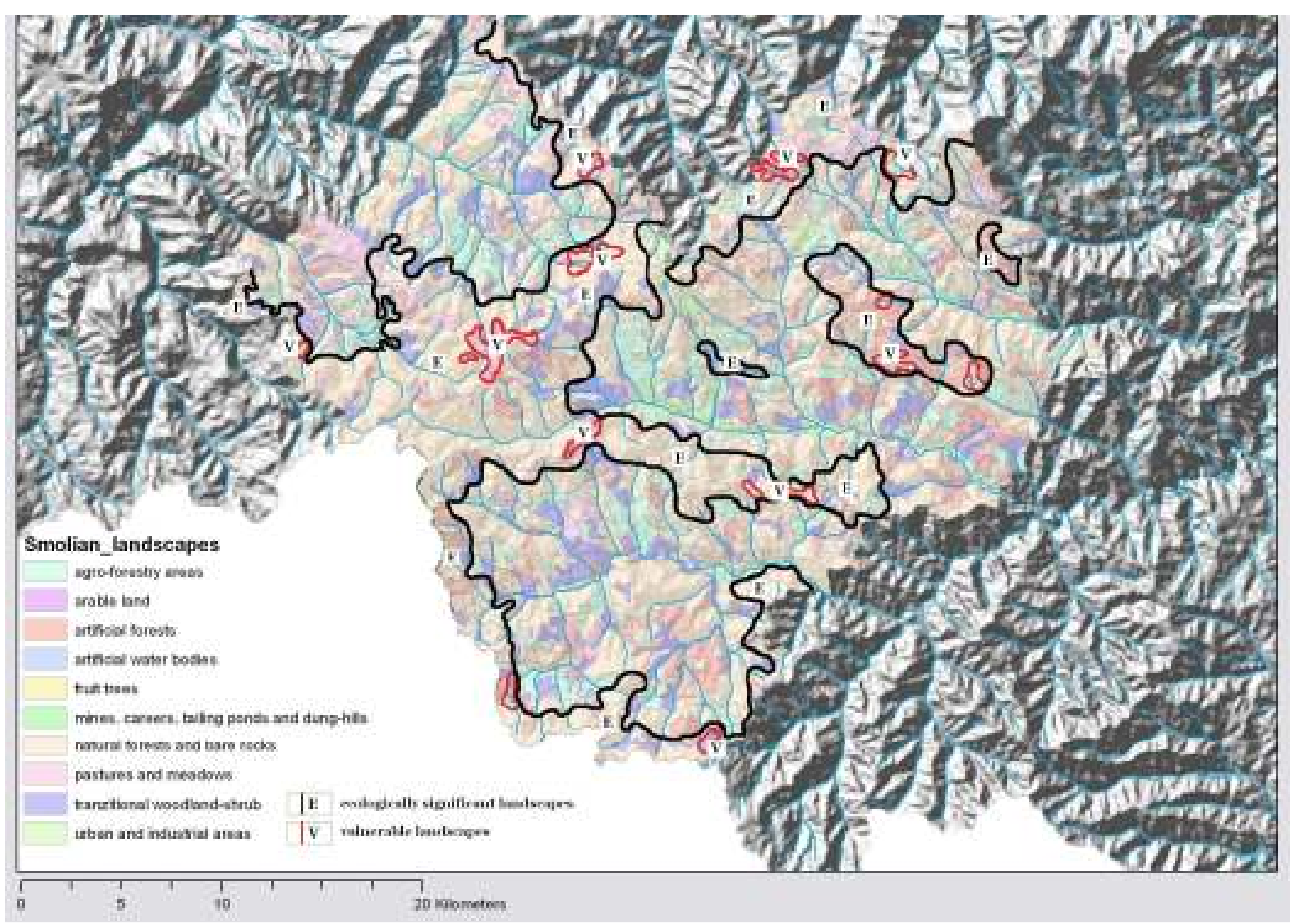

Figure 10. A system of landscapes with ecological significance for the region's sustainability

At this stage of the survey we are in the process of compiling questionnaires for consultation with local experts and representatives of local authorities to examine their attitude to possible changes in the management of the territory and setting new priorities for different sectors of the landscape pattern. Subject of discussions are some issues related to the motivation of local people in respect of the introduction of innovative models of utilization of local resources. At the final stage of the research we intend to develop landscape plans in different scales for individual small watersheds with specific modifications in the character and configuration of landscapes.

\section{Acknowledgements}

We express special thanks to Associate Professor Dr. Stoyan Nedkov at the Bulgarian Academy of Science, who supported this research by kindly providing landscape mapping data from the Project Conservation of Globally Significant Biodiversity in the Landscape of Bulgarian Rhodope Mountains. 


\section{Landscape Planning at the Catchment Scale (The Case Study of Rhodope Mountain Representative Catchments)}

\section{References}

Ahern, J. 1999. Spatial concepts, planning strategies, and future scenarios: a framework method for integrating landscape ecology and landscape planning. Editors: Klopatek J., Gardner R., Landscape Ecological Analysis. Issues and applications, Springer, New York, 175-201.

Blaschke, T. 2006. The role of the spatial dimension within the framework of sustainable landscapes and natural capital, Landscape and Urban Planning, 75, 198-226.

Blaschke, T., J. Petch. 1999. Landscape structure and scale: comparative studies on some landscape indices in Germany and the UK. Editors: Maudsley M., Marshall J., Heterogeneity in Landscape Ecology: Pattern and Scale, International Association of Landscape Ecology UK, Bristol, 75-84.

Borissova, B. Sub-Mediterranean Forest Landscapes of The Eastern RhodopesRhodope and Pontic Landscapes of Strandzha, Editors: Wrbka T., Zmelik K., Grunweis F.M. "The European Green Belt: Borders.Wilderness.Future"; The European Nature Conservation Project "European Green Belt", coordinated by IUCN, Verlag Bibliothek der Provinz, Linz, 214-217.

Botequilha Leitão, A., Ahern, J., 2002. Applying landscape ecological concepts and metrics in sustainable landscape planning, Landscape and Urban Planning, 59, 65-93.

Brunckhorst D., Coop Ph., Reeve I. 2006. 'Eco-civic' optimisation: A nested framework for planning and managing landscapes, Landscape and Urban Planning, 75, 265-281.

Buček, A., Lacina, J. and Löw, J. 1986. Územní systémy ekologické stability krajiny. Životné prostredie, 20, 82-86.

Forman, R. T. T. 1995. Land Mosaics: The Ecology of Landscapes and Regions, Cambridge Univ. Press, Cambridge.

Fry, G. 2001. Multifunctional landscapes - towards transdisciplinary research. Landscape and Urban Planning, 57, 159-168.

Gikov, A., Nedkov St. 2009. Landscape Atlas of the RhodopesRhodope. Rhodope Project (UNDP).

Gustafson, E. J. 1998. Quantifying landscape spatial pattern: what is the state of the art. Ecosystems, 1, 143-156.

Haase, G. 1989. Medium scale landscape classification in the German Democratic Republic, Landscape Ecology, 3, $29-41$.

Hawkins, V., P. Selman. 2002. Landscape scale planning: exploring alternative land use scenarios. Landscape and Urban Planning, 60, 211-224.

Hornung, M., Reynolds B. 1995. The effect of natural and anthropogenic environmental changes on ecosystem processes at the catchments scale, Trends in Ecology \& Evolution, 10, 443-449.

Lavers, C., R. Haines-Young. 1993. Equilibrium landscapes and their aftermath: spatial heterogeneity and the role of new technology. Editors: Haines-Young R., Green D., Cousins S., Landscape Ecology and GIS, Taylor and Francis, London. 57-74.

Miklós, L., 2010. The most successful landscape ecological concepts in the practice. The Problems of Landscape Ecology, 28. 15-22.

Mücher C.A., Klijn J.A., Wascher D.M., Schaminee J.H.J., 2010, A new European Landscape Classification (LANMAP): A transparent, flexible and user-oriented methodology to distinguish landscapes, Ecological Indicators, 10, 87-103.

Nedkov. St. 2009. Analyzing spatial dimensions of ecosystem services and their valuation using GIS: A case study in Smolyan municipality. Problems of geography, 4.

O’Neill, R., Johnson A., King A.. 1989. A hierarchical framework for the analysis of scale. Landscape Ecology, 3, $193-205$.

Potschin, M.B., Haines-Young R.H., 2006. "Rio+10", sustainability science and Landscape Ecology, Landscape and Urban Planning, 75, 162-174.

Von Haaren, Chr., Galler C., Ott St.. 2008. Landscape Planning. The basis of sustainable landscape development. Federal Agency for Nature Conservation, Leipzig. 52.

Zonneveld, I. 1989. The land unit - A fundamental concept in landscape ecology, and its applications. Landscape Ecology, 3, 67-86.

Асенов, Ас. 2006. Биогеография на България. (Assenov, А. Biogeography of Bulgaria) АН-ДИ Андриян Тасев, С., 393410; 464-477. 
Bilyana Borisova 